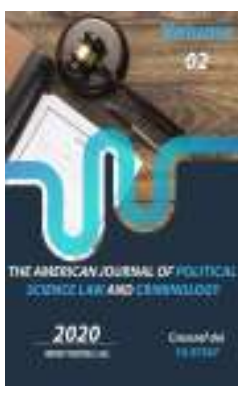

\title{
The Scientific And Theoretical Classification Of Types Of Exemption From Punishment
}

\author{
Samariddin Kamoliddinovich Ochilov \\ Teacher Of The Specialized Branch Of Tashkent State University Of Law Tashkent, Uzbekistan
}

Journal Website:

http://usajournalshub.c

om/index,php/tajpslc

Copyright: Original

content from this work

may be used under the

terms of the creative

commons attributes

4.o licence.

\section{ABSTRACT}

This scientific article addresses the issues of pandemic impunity, the necessity, basis and importance of certain types of impunity in a pandemic, the improvement of certain types of impunity in a pandemic, the legal relationship of illness and disability with a pandemic, some types of impunity in a pandemic. in the application of scientific and theoretical views, the study of problems in legal and law enforcement practice and the coverage of their solutions.

\section{KEYWORDS}

Pandemic, coronavirus, sentence, punishment, exemption from punishment, illness, disability, imprisonment, correctional labor, compulsory community service.

\section{INTRODUCTION}

Dangerous events in the history of mankind have had a serious impact on the various social relations that exist in society, especially legal relations, in their various forms and aspects. In particular, the coronavirus-COVID-19 pandemic, which has caused a number of unprecedented and unresolved problems in the world community and human life today, has challenged the maximum flexibility of any state and society legislation formed in the course of historical development.

In early March this year, the World Health Organization estimated that the spread of coronavirus infection, i.e. COVID-19, had reached a pandemic stage. After that, the concept of "pandemic" was formed in all social 
relations, especially in legal relations, including law enforcement practice, which is not reflected in the legislation, causing or may cause certain legal consequences.

In the Uzbek dictionary [1], the word pandemic (Greek pandemia - whole people, pan - whole, demos - people) refers to the mass spread of an epidemic disease in one country, several countries or continents.

The concept of pandemic is interpreted in the specialized literature [2] of the field (Greek pan - all, pandemos - general, universal) "pandemic" as a widespread epidemic disease among the population, covering several countries.

Pandemic legislation in legal relations and the existence of a number of problems that need to be addressed in law enforcement practice, some views have been formed on how to address these problems.

It has been acknowledged that the coronavirus situation not only forces us to reconsider the usual relationships we are accustomed to in the first place, but also to look at them from a different perspective, edit some, and rethink and plan [3] our next lifestyle.

The pandemic began to have a significant impact on social relations over a short period of time. Therefore, the regulation of social relations began to require the development of measures to address the problems that have arisen. In this regard, representatives of other sectors also expressed theoretical views on the problems that have arisen in the context of the impact of the pandemic on social relations and their solutions.

According to scientists [4], the pandemic has radically changed the worldview of politics, economics, social relations, globalization, the world, and the coronavirus has alerted humanity. It should be noted that the lack of social cohesion in some developed countries has led to unsuccessful attempts to curb COVID-19, as well as confusion and depression.

Given these fundamental changes that have taken place in human society, in our country, in the context of a pandemic, it is necessary to determine some parameters of post-pandemic social life and development. Because COVID2019 is not the first and last pandemic. In the past, our country and our people, like the world community, may face such global threats.

The flexibility of the legislation to the conditions of the pandemic, as well as the problems that have arisen in this regard, have also begun to be noted. It is clear from the legislators [5] that there is a gap in our laws governing social life during the pandemic, therefore, it was noted that so far one law, several decrees and decisions have been adopted, which in the context of this pandemic the state plays an important role in regulating issues such as protection of the population, employment, strengthening the lifestyle of the population.

The pandemic has today taken the form of a legal institution that plays a special and important role in legal relations. However, the lack of a legal definition of a pandemic at the same time calls for its recognition as a legal institution. Therefore, in some types of legal relations, in particular in the protection of the economy, the main attention was paid to ensuring the stability of civil law relations by ensuring the stability of their activities by protecting the interests of the participants of civil legal relations.

It should be noted that the study of legal regulation of criminal relations in a pandemic is one of the current issues. This is because the participants in the criminal-legal relationship, to be more precise, the subject of the crime are also in a state of dispute over what kind of legal 
relationship they will face if they fall into the scope of a pandemic. To date, no new norms have been established to address changes in criminal law in the context of a pandemic.

Plenum of the Supreme Court of the Republic of Uzbekistan 2020 On April 28, the courts adopted Resolution No. 8 [6] "On some issues of application of the legislation in connection with the introduction of measures to prevent the spread of coronavirus infection (COVID-19) in the territory of the Republic of Uzbekistan."

The decision of the Supreme Court of the Republic of Uzbekistan does not preclude the introduction of quarantine, detention, house arrest, statutory coercive measures, as well as parole and commutation of sentences. timely application of measures and materials on the application, modification, revocation, extension of precautionary measures, release from punishment due to illness or disability, parole and commutation of sentence, compliance with the conditions of quarantine, including the use of videoconferencing should take remedial action.

The explanations in the decision of the Plenum of the Supreme Court of the Republic of Uzbekistan envisage the introduction of measures to prevent the spread of coronavirus infection (COVID-19) in the territory of the Republic of Uzbekistan, problems in judicial practice, as well as uniform and correct application of substantive and procedural law. However, in the context of the pandemic, the courts did not provide explanations on the application of certain types of impunity to convicts convicted of criminal offenses.

Professional criminal law, by its very nature, is important in that it can perfectly regulate any criminal relationship. For this reason, it is important to study the application of certain forms of impunity in a pandemic within the framework of the Institute of Impunity, which we are studying.

In particular, today the country has developed and implemented priorities [7] for further improvement of the regulatory framework in the field of enforcement of criminal penalties. There is a need to develop scientific and theoretical solutions.

According to Article 75 [8] of the Criminal Code of the Republic of Uzbekistan, a person should be released from serving a sentence if he or she suffers from a mental illness or other serious illness that prevents him or her from serving the sentence.

According to this article, a person can be released from imprisonment, correctional labor, compulsory community service, transfer to a disciplinary unit, restriction of service due to illness or disability.

Comments on the Criminal Code state [9] that it is the physical condition of the patient that makes it inappropriate to impose an actual punishment on him and that it is pointless to continue serving the sentence.

Other legal literature [10] considers the loss or reduction of the social risk of a convicted person as an additional reason when considering the release of a person suffering from a serious illness, on the basis of which it is not possible to fully apply criminal measures against him. intended.

In accordance with the first part of Article 75 of the Criminal Code, the Plenum of the Supreme Court of the Republic of Uzbekistan in its decision No. 28 of 27 December 2016 [10] "On the jurisdiction on early release and commutation of sentence" states that is exempted from serving a sentence if he suffers from a mental illness to the extent that he is unable to do so, as well as from another serious 
illness that prevents him from serving his sentence.

Also, when considering the relevant representation of the executive body in this decision of the Plenum of the Supreme Court of the Republic of Uzbekistan, the court approved the decision of the Ministry of Internal Affairs and the Ministry of Health dated 13 August 2008 [12] The Ministry of Internal Affairs of the Republic of Uzbekistan will evaluate the conclusion of the special medical commission on the basis of the approved "List of diseases that are the basis for the release of convicts suffering from serious illness due to illness."

An application for release of a convict on the basis of incapacity for work shall be submitted by the executive body on the basis of the conclusion of a medical-labor expert commission, and a petition for release of a woman on maternity leave shall be based on a medical document entitling her to such leave. is entered.

For example, under the leadership of Deputy Chairman of the Supreme Court of the Republic of Uzbekistan Bakhtiyor Isakov in the Amudarya district of the Republic of Karakalpakstan during the mobile reception were considered requests for early release of 7 convicts serving sentences. On the same day, they were released on parole under Article 73 of the Criminal Code. Also, the petition of another person for release from punishment due to illness, disability was considered, and in accordance with Article 75 of the Criminal Code, the applicant's application was fully satisfied [13].

The current legislation defines the measures to be taken when a convict falls ill. If a convict becomes ill during the sentence, treatment and preventive measures shall be taken with him in accordance with the procedure established by the Criminal Procedure Code of the Republic of Uzbekistan [14].

One of the most pressing issues today is the consideration of the application of certain types of impunity to convicts convicted of crimes related to the introduction of measures to prevent the spread of coronavirus infection

(COVID-19) in the territory of the Republic of Uzbekistan.

It should be noted that there is no clear and complete view on the application of certain types of impunity in the context of a pandemic in scientific-theoretical views, legislation, case law or legal explanations.

The need to apply certain types of impunity in the context of a pandemic is explained by the fact that there are some socio-economic and legal problems that need to be addressed in this regard. In particular, the fact that a defendant contracted a coronavirus infection (COVID-19) during the course of a criminal case may result in the conviction and organization of the sentence; physical torture of the convict due to this disease, punishment by nature for his actions, lack of vaccine against coronavirus infection (COVID-19), lack of medical guarantee of complete recovery from this disease, the issue of continuing the sentence after recovery; examples include problems such as the quarantine complicating the economic situation in the workplace or leaving the patient with physical complications due to quarantine in the conduct of labor activity by a convict sentenced to correctional labor or compulsory community service.

Based on the above-mentioned scientific and theoretical views, law enforcement practice, legal analysis, it is necessary to clarify whether or not coronavirus infection (COVID-19) is a serious disease, and therefore to include it in the list of diseases that prevent punishment. 
In order to expand the use of impunity in the event of pandemic illness or incapacity for work, Article 75 of the Criminal Code provides that "Those sentenced to imprisonment for less serious or less serious crimes shall be sentenced to compulsory community service or correctional labor. Individuals who fall ill with a pandemic during their imprisonment will be exempted from serving their sentences".

We believe that these theoretical proposals will play an important role in addressing some of the problems that may arise in connection with the introduction of measures to prevent the spread of coronavirus infection (COVID-19) in the territory of the Republic of Uzbekistan, but also in the future pandemic.

\section{REFERENCES}

1. Annotated dictionary of the Uzbek language. State Scientific Publishing House "National Encyclopedia of Uzbekistan". Tashkent. The letter “P”, page 212, page 331.

http://n.ziyouz.com/books/uzbek_tilining.

2. Explanatory dictionary and reference book on veterinary microbiology, virology, epizootology: $X$. Salimov and others Тошкент: «Tafakkur», 2013. page 84, page 208.

3. What the coronavirus changes: socio-legal aspects. R. Davletov - Ministry of Justice. Official website of the Ministry of Justice of the Republic of Uzbekistan. April 14, 2020. https://www.minjust.uz/uz/presscenter/news/98993/.

4. Life after the pandemic: What should we pay special attention to in the future? R. Kholmurodov - Rector of Samarkand State University. Official website of the National News Agency of Uzbekistan. May 20, 2020. http://uza.uz/oz/society/pandemiyadan- keyingi-ayet-kelgusida-nimalarga-alo-idaetibor-20-05-2020.

5. Together, we will overcome all difficulties. K. Kasimova - Deputy of the Legislative Chamber of the Oliy Majlis of the Republic of Uzbekistan. Official website of the People's Democratic Party of Uzbekistan. May 19, 2020. http://xdp.uz.

6. Resolution of the Plenum of the Supreme Court of the Republic of Uzbekistan dated April 28, 2020 No 8 "On some issues of application of the legislation in connection with the introduction by the courts of measures to prevent the spread of coronavirus infection (COVID-19) in the Republic of Uzbekistan." https://lex.uz/docs/4805217.

7. Resolution of the President of the Republic of Uzbekistan dated November 7, 2018 No PP-4006 "On measures to radically improve the criminal-executive legislation." National Database of Legislation, November 8, 2018, 07/18/4006/2166-сон, 13.12.2018 й., 06/18/5597/2300-соH. https://lex.uz/docs/4045443.

8. Criminal Code of the Republic of Uzbekistan. Bulletin of the Supreme Council of the Republic of Uzbekistan, 1995, No. 1. https://www.lex.uz/acts/111453.

9. Comments on the Criminal Code of the Republic of Uzbekistan. Ministry of Internal Affairs of the Republic of Uzbekistan.// .// - Т.: «Адолат». Team of authors. 1997. page 164. page 624.

10. Rustamboev M.H. Course of criminal law of the Republic of Uzbekistan. Volume II. General section. The doctrine of punishment. Textbook for higher education institutions.// - T.: «Ilm Ziyo», 2011. page 177. - page 304.

11. Resolution of the Plenum of the Supreme Court of the Republic of Uzbekistan No. 28 
Doi: https://doi.org/10.37547/tajpslc/Volume02Issue11-18

of December 27, 2016 "On the

jurisprudence on early release and commutation of sentence."

https://www.lex.uz/docs/3115182.

12. Resolution of the Ministry of Internal Affairs of the Republic of Uzbekistan No. 12 and 9 of August 13, 2008 "On approval of the Rules of medical examination of prisoners with serious illness and their release from serving a sentence due to illness" (09.09.2008). , list number: 1854). Collection of Legislation of the Republic of Uzbekistan, 2008, No. 37-38, Article 385. https://lex.uz/ru/docs/1390458\#1390635.

13. The mobile reception, 7 convicts were released early. Amunews.uz website. http://amunews.uz/news/4489.

14. Criminal Enforcement Code of the Republic of Uzbekistan. Bulletin of the Oliy Majlis of the Republic of Uzbekistan, 1997, No. 6, Article 175 .

https://lex.uz/ru/docs/163629\#170953. 